\begin{tabular}{c}
\hline Review of \\
ECONOMICS \\
and \\
INSTITUTIONS
\end{tabular}

Review of Economics and Institutions ISSN 2038-1379 DOI:10.5202/rei.v9i1.214

Vol. 9 - No. 1, Spring-Summer 2018 - Article 3

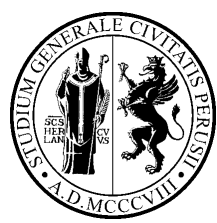

www.rei.unipg.it

\title{
Changing Sexual Regulations in the U.S. from 1990 to 2010: Spatial Panel Data Analysis
}

\author{
Feler Bose ${ }^{凶}$ \\ Indiana University East
}

\author{
Jeffry A. Jacob \\ Bethel University
}

\begin{abstract}
Understanding legal regulation on sexual practices is a field in its infancy. In this paper we analyze the factors driving these sexual regulations using a novel dataset for the U.S. for the years 1990 to 2010. We first introduce the index of sexual regulation (ISR) and then using a spatial lag fixed effects estimator that accounts for spillover effects from neighboring states, we find that citizen's ideology, population density, household income and median age are associated with a weaker sexual regulation while government ideology has a slight positive association with the overall sexual regulation. We also examine two dimensions of sexual practice regulation looking at the index of marriage practice regulation (IMPR) and sex crime regulation (ISCR). In the case of IMPR, our findings indicate that a more liberal government ideology, a higher share of population with the college degree and a higher median age are associated with a more liberal index of marriage practice regulation.
\end{abstract}

JEL classification: K36; K42; K49

Keywords: Index of Sexual Regulation, Spatial Panel Data Analysis, Index of Marriage Practice Regulation, Citizen Ideology, Index of Sex Crime Regulation

$\triangle$ Address: School of Business and Economics, Indiana University East, Richmond, 47374, USA 32211, U.S.A. Phone: +1-765-973-8538. Email: felerbose@gmail.com).

\section{Recommended Citation}

Bose, F., Jacob, J. A., (2018). Changing Sexual Regulations in the U.S. from 1990 to 2010: Spatial Panel Data Analysis. Review of Economics and Institutions, 9(1), Article 3. doi: 10.5202/rei.v9i1.214

Retrieved from http://www.rei.unipg.it/rei/article/view/214 


\section{Introduction}

The study of regulations on individual sexual practices in economics is still at its infancy. Numerous scholars in other fields have investigated the possible outcomes of sexual regulations such as economic freedom, development, etc. They include Aldous Huxley (1932), Sigmund Freud (Freud, 1908: 2000-2004), Joseph Unwin (1935, 1940, 1934), and Pitirim Sorokin (1956). All of these authors saw lax regulations on sexual practices as a detriment to economic outcomes with Unwin completing a thorough historical analysis. Unwin (1934) writes: "[E]ach society reduced its sexual opportunity to a minimum and, displaying great social energy, flourished greatly. Then it extended its sexual opportunity; its energy decreased, and faded away. The one outstanding feature of the whole story [from dozens of cases] is its unrelieved monotony". Unwin (1934) further states: "[A]ny human society is free to choose either to display great energy or to enjoy sexual freedom; the evidence is that it cannot do both for more than one generation". While Unwin did some detailed observational work, the lack of in-depth analysis on sexual regulations is due to the lack of data that would allow for econometric analysis.

Recently, a study measuring worldwide trends in the regulation of sexual crimes was completed for 194 countries from 1945 to 2005. The study looked at sex-law reforms along four dimensions, adultery, sodomy, rape, and child sexual abuse (Frank et al., 2010), finding a loosening of regulations regarding adultery and sodomy, but a tightening of the criminal code on rape and child sexual abuse. According to the authors, the former would indicate a change in the understanding of sex from a procreational/family role to an individual role. Ruger and Sorens (2016) develop a comprehensive Index of Personal and Economic Freedom for the 50 U.S. states. Originally, the index covered regulations on prostitution and homosexual marriage only but, then, it has been extended to cousin marriage (albeit for a limited number of years).

Bose (2015) develops, for the US states, a broader measure of sexual practices' regulations covering sixteen dimensions ("sexual freedom index"), for the period between 1990 to 2010. One of the contributions of the present paper is to extend and update the sexual freedom index developed by Bose (2015). Second, we aim to identify those factors that influence the regulation on marriage practices and that on sex crimes. Third, our paper improves upon the econometric analysis by controlling for possible influences across neighboring states ("spillovers") in the regulation of sexual practices and idiosyncratic state heterogeneity using a spatial autoregressive panel data regression model and including state fixed effects. We find that citizens' ideology, population density, household income and median age are associated with a weaker sexual regulation while government ideology has a slightly positive association with the sexual practices regulation. In the case of marriage practice regulation, our findings indicate that a more leftist government ideology, a higher share of population with the college degree and a higher median age are associated with a more liberal regulation. We also find that spatial spillover effects for both dimensions of regulation (marriage practice and sex crimes) are statistically significant, implying that the change of sexual practices' regulation is affected by the reforms implemented in neighboring states. One channel through which this spillover could occur is the movement of workers across state borders.

Copyright ( 2018 University of Perugia Electronic Press. All rights reserved. 
Section 2 provides a literature review. Section 3 describes the data used in our analysis. Section 4 provides the model. Section 5 shows the results from the spatial panel regressions. Section 6 concludes.

\section{Literature Review}

In the economic literature, the legal discipline on divorce and homosexuality are the dimensions of sexual practices regulation that have gained attention. Other sexual practices such as prostitution, adultery, fornication, etc., have been object of economic analysis but from a theoretical perspective only (Posner, 2007, Cameron, 2002). This section deals with norms, laws, and dead letter laws concerning sexual practices defined in a broad sense, building up a general framework useful for the creation of the index of sexual practices' regulation which is introduced below.

\subsection{Norms, Laws, and Sexual Regulations}

One of the issues that come up when dealing with sexual regulations is dead letter laws, i.e. laws that are on the books, but possibly not enforced.

Cohabitation and adultery, while de jure illegal in some states are de facto not strictly enforced by the states. However, there are many instances where cohabitation laws are indirectly enforced. For example, cohabitation laws come into play in child custody disputes and in divorce cases. In Muller v. Muller (711 N.W.2d 329 (2006) 474 Mich. 1074) a circuit court in Michigan had ordered that "neither party shall have an unrelated member of the opposite sex overnight while having parenting time with the minor children," while this decision was appealed all the way to the Supreme Court of Michigan, the higher court did not reverse the decision. Further, because court cases in the U.S. are only recorded when a case is appealed it is possible that occasional cohabitation and adultery cases are dealt with by the courts (see Coleman, 1991) but because it is not recorded it is unclear how many cases are actually litigated. In a news article, it was stated that the state of Virginia successfully prosecuted eight cases for adultery in a decade ${ }^{1}$. Hence, one must be careful not to assume a law is dead.

This research is relevant to a larger discussion about the relationship between law and social norms. Strong social norms create pressures that constrain the behavior of individuals. The threat of social ostracism and shame are powerful forces for social conformity. In a common law system, the law is expected to reflect social norms. "According to an old principle in jurisprudence, judges must discover common law in social norms rather than invent law in light of their own preferences" (Cooter, 1997). The law then supplements the pressure that emerges from social norms.

Private enforcement and state enforcement typically complement each other. The cooperation of citizens with officials increases the effectiveness of state enforcement and lowers its costs; the backing of state officials increases the effectiveness of private enforcement and lowers its risks. Conversely, laws that are inconsistent with social norms are perceived as irrelevant or unjust by many citizens, who then are reluctant to help the state detect and punish individuals who break such laws (Cooter, 1997).

When laws support social norms, they are more likely to be enforced. When laws conflict with social norms, they are more likely to be disobeyed and under-enforced.

1 https://www.apnews.com/98fba5471a8d47f5803c190b79fcd27b (accessed May 10, 2018). 
Social norms create significant social pressure, and they do not emerge from law. Thus, our attempt to measure law on sexual practices is an imperfect method for measuring freedom. When measuring regulations on sexual practices, it is important to recognize that private enforcement of social norms reduces human freedom regardless of state enforcement. Posner notes that "norm internalization reduces human freedom, viewed functionally in terms of scope of choice rather than formalistically as freedom from legal constraints" (Posner, 1997).

To achieve a better proxy of social norms, it is important to aim measurements toward smaller constituencies, and more democratic processes. Clearly a U.S. Supreme Court decision may not accurately reflect social norms because the Supreme Court is removed from any democratic process.

Our measurement of sexual regulations should be directed at state level constituencies in order to more accurately reflect differences in social norms or median voter preferences as, it has been shown, they vary between states. Although Supreme Court decisions certainly influence state legislatures, our measure should focus on what is written in state laws. Although a Supreme Court decision may render a statute null, the index will not change values until the state legislature changes the law. Further, our index does reflect the decisions of state courts because state courts more closely reflect the preferences of the state voters than the federal courts. Roe v. Wade, 410 U.S. 113 (1973) provides an excellent example of conflicting desires between state and federal courts. Numerous states have instituted 'trigger laws' which would immediately recriminalize abortions if the Supreme Court were to overturn Roe v. Wade (Smock, 2004). State politicians are more responsive to the median voter preferences within their state than the federal politicians. It is important to consider these complexities because they more closely reflect actual voter preferences. Voter preferences, in turn, more closely reflect the prevailing social norms.

A telling example comes with the interracial marriage law in Alabama. In 2000, Alabama had a ballot measure to repeal an amendment in their constitution banning interracial marriage. The repeal passed with $59 \%$ of the vote. This indicates that social norms in Alabama took a long time to change ${ }^{2}$ even though the Supreme Court legalized interracial marriage in $1967^{3}$.

It is also important to note that laws lag behind social norms. A certain behavior may be unacceptable under the prevailing social norms, but it may not become penalized in state law until it is apparent that the social norms are not sufficient for preventing breaches of the standard. This occurred in the 1800s with the issue of abortion where the Southern states in the U.S. did not have abortion laws because social norms were sufficiently strong to discourage abortions, whereas the Northeastern states did (Olasky, 1995).

\subsection{Economic and other literature on divorce and homosexuality}

Numerous economic papers have dealt with divorce laws, specifically, the shift from mutual consent to unilateral divorce, starting from the seminal work by Becker (1981).

\footnotetext{
${ }^{2}$ http://ballotpedia.org/wiki/index.php/Alabama_Interracial_Marriage,_Amendment_2_\%282000 $\% 29$ (accessed April 18, 2013).

${ }^{3}$ Loving v. Virginia, 388 U.S. 1
} 
"Although divorce might seem more difficult when mutual consent is required than when either alone can divorce at will, the frequency and incidence of divorce should be similar with these and other rules if couples contemplating divorce can easily bargain with each other" (Becker, 1981).

Various empirical studies have tested Becker's hypothesis under low transaction costs. Peters (1986) finds that the change from mutual consent to unilateral divorce had no effect on the number of divorces in the U.S., but did affect compensation, i.e., spousal support at divorce is lower in unilateral states. By controlling for state and year-specific effects, Friedberg (1998) finds that the switch had a positive and permanent effect on the divorce rate. However, it only explains a $17 \%$ change in divorce rates. Wolfers (2006) separates pre-existing time trends from dynamic effects of a policy shock, arguing that the effects identified by Friedberg (1998) are temporary and have no long-term consequence on the number of divorces. The pent-up demand for divorce is released with the law change and then trails off.

However, another line of research suggests the Coasian approach is incomplete and that non- Coasian assumptions are needed, i.e. high cost of bargaining. For example, Rasul (2006) finds that marriage rates are lower under unilateral divorce. In the long run, the easing of divorce laws resulted in lower divorce rates due to the "selection effect" as individuals more carefully select their spouse. Allen et al. (2006) show that, in the U.S., the unilateral divorce regime increased the length of a spousal search by 1 to 2 months. However, in the short run, easing divorce laws increased the existing stock of married couples divorcing, which is usually referred to as the "pipeline effect" (see also Wolfers 2006).

Mataucha and Rasul (2008) study the "selective" and "incentive" effects on divorce within a model of contract marriage. They find that couples who marry after the enactment of unilateral divorce laws are less likely to divorce (due to the selection effect) than couples who married when the laws are passed and suddenly find themselves given a new incentive, an easier way out, complete with lower exit costs (this is the incentive effect ${ }^{4}$ ). It would follow that states adopting unilateral divorce would experience high divorce rates due to this incentive effect (see Rasul 2006).

There is also an enormous literature in psychology, sociology, psychiatry, child development, etc., which shows that parental divorce is negatively related to a wide variety of children and households' performance indicators. These include effects on educational attainment and learning capacity, effects on household income, increases in crime, abuse, and neglect and the resulting costs of state intervention, children's health outcome (mental and emotional), and the effects of spiritual capital (see Fagan and Churchill 2012 for a review). While this literature is large, one must be careful about the casual interpretation as some of the outcomes in the observable variables could be due to unobservable features between those families that choose to divorce and those who do not divorce, leading to overestimating the effect of divorce.

There is a large literature on homosexuality in fields such as biology, genetics, psychiatry, neuroscience, psychology, political science, and gender studies. Tolerance towards homosexuality usually increases with the level of economic development; however, the poorer within these countries are less tolerant towards homosexuality (Andersen and Fetner, 2008). Berggren and Nilsson (2013) also find that economic freedom is related to tolerance to homosexuality especially in the long run, but this is

4 This is similar to the Pipeline effect as noted by Rasul (2006). 
not true for other categories like race. Further, there is a large literature that delves into the compensations' gap between heterosexual employees and non-heterosexual employees. In general, heterosexual men earn more than non-heterosexual men, but the results are reversed for women. This could be due to different discrimination patterns for men and women or other issues such as the role that child rearing might play. Some studies separate out heterosexual men who are married with heterosexual men who are cohabitating with a female and compares them to cohabiting homosexual men and women. These studies on compensation differentials are summarized in Botti and D'Ippoliti (2014). The Williams Institute of UCLA School of law has tried to measure the cost of homophobia, finding that this kind of discrimination negatively affects employers and government's performance in terms of productivity, retention, recruitment, and public expenditure (Mallory et al. 2018).

\section{Model}

In this paper, we study the determinants of sexual practices regulation (ISR), and its underlying components -IMPR and ISCR- in a panel of US states. Our explanatory variables include measures for government and citizen ideology, state income and education levels, median age, population density, religious and racial fractionalization. In addition to being associated with state specific variables, a state's regulation of these sexual practices can be influenced by the prevailing regulation in its neighboring states. A failure to account for these "spillover" effects can result in overstating the impact of a state's own characteristics. We therefore allow for spatial spillovers by including a spatially lagged dependent variable. The spatial weights are based on state contiguity matrix. Further, there can be another source of an omitted variable bias due to state-specific unobserved heterogeneity. To control for this, we employ a fixed-effects estimation method. Thus, our estimating equation can be represented by the following specification:

$$
s_{i t}=\lambda \sum_{j=1}^{N} w_{i j} s_{j t}+\sum_{k=1}^{K} \beta_{k} x_{k i t}+v_{i}+\mu_{i t}
$$

where $s_{i t}$ is an individual dimension of the sexual practices' regulation for state $i$ at time $t, w_{i j}$ is an element of the spatial weight matrix denoting the contiguity relationship between states $i$ and $j, x_{k i t}$ denotes the set of covariates, $v_{i}$ is a state-specific fixed effect, and $\mu_{i t}$ is the idiosyncratic error term. All variables are first transformed through an orthogonal transformation to remove the fixed effects and then the model is estimated using a quasi-maximum likelihood estimator derived by Lee and $\mathrm{Yu}(2010)$.

\section{Data}

In this section we first focus on the dependent variable and then discuss the independent variables used in our analysis.

Copyright $(2018$ University of Perugia Electronic Press. All rights reserved. 


\subsection{Dependent Variable}

Our dependent variables are the two components of the index of sexual regulations (ISR) -index of marriage practice regulation (IMPR), index of sex crime regulation (ISCR) as well as the ISR. Defining and coding sexual freedom is both an art and a science. The measure of sexual regulations used is this paper comes from Bose (2015). Historically, both family law and criminal law has supported limiting sexual activity to the realm of marriage to protect the sanctity of marriage (Murray, 2009). Hence, the ISR is divided into two broad categories: marriage practice regulation ${ }^{5}$ and sex crime regulation (see Table 1). Each variable is coded on a four-point scale $(0,1,2,3)$. A value of 0 reflects the lowest level of freedom or the most stringent level of regulation, a value of three represents the highest level of freedom or no regulation. The variables are coded with a zero if, in a given state year, the behavior is punishable as a felony. The variable is coded with a one if the behavior is punishable as a misdemeanor, a two either if the behavior is punished as a petty crime, (minimal fine, no jail time) or if it is a misdemeanor in certain parts of the state and not in others. A petty offense is usually not considered a crime (Torcia, 1993). Finally, a behavior that is not punished in a given state year receives a value of three.

Table 1: Variables used for developing the ISR and the category each variable falls under.

\begin{tabular}{ll}
\hline Variables & Category \\
Adultery & Marriage Practice \\
Bestiality & Sex Crime \\
Homosexual Marriage (Civil Unions) & Marriage Practice \\
Recognition of Homosexual Marriage & Marriage Practice \\
Abortion Prohibitions & Sex Crime \\
Prostitution Laws for Pimp & Sex Crime \\
Prostitution Laws for Prostitute & Sex Crime \\
Prostitution Laws for John & Sex Crime \\
Polygamy (Bigamy) & Marriage Practice \\
Divorce & Marriage Practice \\
Cohabitation laws & Marriage Practice \\
Miscegenation laws & Marriage Practice \\
Sodomy Laws & Sex Crime \\
Marrying Close Blood (first cousin) & Marriage Practice \\
Fornication Laws & Sex Crime \\
Age of Consent & Sex Crime
\end{tabular}

Certain variables, including most falling under the family law, could not be coded using the scale based on the distinction among felony/misdemeanor/petty crime. For each sexual practice, some discretionary coding has been applied. Many of the practices (relationships prevented to protect marriage) are prohibited in family or marriage law,

${ }^{5}$ The marriage freedom category reflects the changing laws instituted to protect the family by protecting the meaning of marriage to be of one male and one female in union. 
but do not carry criminal penalties. For these variables, it has been necessary to adjust the coding method to consider the relative legal obstacles of obtaining legal recognition of certain relationships. For an outline of the coding procedure used for each variable see Table 2.

Table 2: Coding method used for creating the Index of Sexual Regulation.

\begin{tabular}{|c|c|c|c|c|}
\hline Variable & 0: Most Regulated & 1 & 2 & 3: Least Regulated \\
\hline $\begin{array}{l}\text { General } \\
\text { Adultery, Prostitution } \\
\text { (pimps, prostitutes, } \\
\text { and Johns), Bestiality, } \\
\text { Fornication, } \\
\text { Cohabitation, Sodomy, } \\
\text { Polygamy, } \\
\text { Miscegenation }\end{array}$ & Felony & Misdemeanor & $\begin{array}{l}\text { Misdemeanor in } \\
\text { limited } \\
\text { regions/Petty } \\
\text { Crime }\end{array}$ & Not a Crime \\
\hline $\begin{array}{l}\text { Age of Consent } \\
\text { (Minimum age that } \\
\text { may consent to legal } \\
\text { sexual activity) }\end{array}$ & 19 and up & 17,18 & 15,16 & 14 and under \\
\hline Close Blood Marriage & $\begin{array}{l}\text { Cousin Marriage } \\
\text { prohibited in all } \\
\text { circumstances }\end{array}$ & $\begin{array}{l}\text { Cousin Marriage } \\
\text { allowed with } \\
\text { proof of infertility } \\
\text { or between } \\
\text { person over the } \\
\text { age of } 50\end{array}$ & & $\begin{array}{l}\text { Cousin Marriage } \\
\text { allowed without } \\
\text { reservations }\end{array}$ \\
\hline $\begin{array}{l}\text { Divorce } \\
\text { (requirements for legal } \\
\text { divorce) }\end{array}$ & $\begin{array}{l}\text { Not routinely } \\
\text { allowed }\end{array}$ & Fault & $\begin{array}{l}\text { Mutual } \\
\text { Consent/No } \\
\text { Fault }\end{array}$ & None (Unilateral) \\
\hline Homosexual Marriage & Prohibited & Civil Unions & & Allowed \\
\hline $\begin{array}{l}\text { Abortion } \\
\text { (Legality of Abortions } \\
\text { in the absence of Roe } \\
v . \text { Wade) }\end{array}$ & Prohibited & & & Allowed \\
\hline
\end{tabular}

For each state, the value of ISR has been obtained as simple sum of various sub-components. The highest value attached to a state is equal to $48(3 \times 16)$. For the sub-indices of IMPR and ISCR, the highest score is $24(3 \times 8)$.

We have made small changes to the Bose's (2015) sexual freedom index based on updated data. Table 3 shows the average state level ISR. More than half of the states have seen an increase in sexual freedom between 1990 and 2010, while the other half have either kept the same level of regulation or show an increase in the stringency of sexual practices law. 
Table 3: State level summary of the Index of Sexual Regulation

\begin{tabular}{|c|c|c|c|c|}
\hline State & Mean & Std. Dev & Min & Max \\
\hline Alabama & 24.05 & 0.22 & 24 & 25 \\
\hline Alaska & 30.00 & 0.00 & 30 & 30 \\
\hline Arizona & 19.90 & 1.92 & 18 & 23 \\
\hline Arkansas & 23.95 & 1.02 & 23 & 25 \\
\hline California & 29.00 & 0.00 & 29 & 29 \\
\hline Colorado & 24.00 & 0.00 & 24 & 24 \\
\hline Connecticut & 31.76 & 2.23 & 29 & 37 \\
\hline Delaware & 22.43 & 1.08 & 22 & 25 \\
\hline Florida & 22.00 & 0.00 & 22 & 22 \\
\hline Georgia & 23.86 & 1.49 & 22 & 25 \\
\hline Hawaii & 33.52 & 0.51 & 33 & 34 \\
\hline Idaho & 18.62 & 0.80 & 17 & 19 \\
\hline Illinois & 23.86 & 1.49 & 22 & 25 \\
\hline Indiana & 28.10 & 1.14 & 26 & 29 \\
\hline lowa & 28.14 & 1.93 & 26 & 32 \\
\hline Kansas & 23.00 & 0.00 & 23 & 23 \\
\hline Kentucky & 24.81 & 0.60 & 23 & 25 \\
\hline Louisiana & 21.00 & 0.00 & 21 & 21 \\
\hline Maine & 27.19 & 0.40 & 27 & 28 \\
\hline Maryland & 28.43 & 1.08 & 28 & 31 \\
\hline Massachusetts & 16.29 & 4.23 & 13 & 22 \\
\hline Michigan & 14.00 & 0.00 & 14 & 14 \\
\hline Minnesota & 20.95 & 1.02 & 20 & 22 \\
\hline Mississippi & 15.62 & 0.50 & 15 & 16 \\
\hline Missouri & 23.33 & 1.59 & 22 & 26 \\
\hline Montana & 25.00 & 1.45 & 23 & 26 \\
\hline Nebraska & 27.05 & 1.02 & 26 & 28 \\
\hline Nevada & 30.14 & 2.15 & 25 & 31 \\
\hline New Hampshire & 25.43 & 1.96 & 24 & 29 \\
\hline New Jersey & 32.00 & 0.00 & 32 & 32 \\
\hline New Mexico & 28.48 & 0.51 & 28 & 29 \\
\hline New York & 26.00 & 0.00 & 26 & 26 \\
\hline North Carolina & 19.71 & 0.46 & 19 & 20 \\
\hline North Dakota & 21.38 & 0.80 & 21 & 23 \\
\hline Ohio & 32.95 & 0.22 & 32 & 33 \\
\hline Oklahoma & 17.00 & 0.00 & 17 & 17 \\
\hline Oregon & 26.05 & 1.02 & 25 & 27 \\
\hline Pennsylvania & 26.14 & 1.01 & 25 & 28 \\
\hline Rhode Island & 24.57 & 1.54 & 23 & 26 \\
\hline South Carolina & 21.00 & 0.00 & 21 & 21 \\
\hline South Dakota & 26.14 & 2.59 & 22 & 28 \\
\hline Tennessee & 29.00 & 2.26 & 26 & 31 \\
\hline Texas & 27.00 & 1.45 & 26 & 29 \\
\hline Utah & 17.10 & 0.62 & 16 & 18 \\
\hline Vermont & 30.19 & 0.87 & 30 & 34 \\
\hline Virginia & 19.00 & 0.00 & 19 & 19 \\
\hline Washington & 25.57 & 1.21 & 25 & 28 \\
\hline West Virginia & 20.76 & 1.51 & 20 & 27 \\
\hline Wisconsin & 18.19 & 0.40 & 18 & 19 \\
\hline Wyoming & 27.81 & 0.40 & 27 & 28 \\
\hline
\end{tabular}


During our period of study, Michigan, Mississippi and Ohio have the highest degree of regulation on sexual practices while Hawaii, New Jersey and Connecticut are the most liberal states. Figure 1 shows the average ISR value for the continental US states.

Figure 1: Average Index of Sexual Regulation in USA

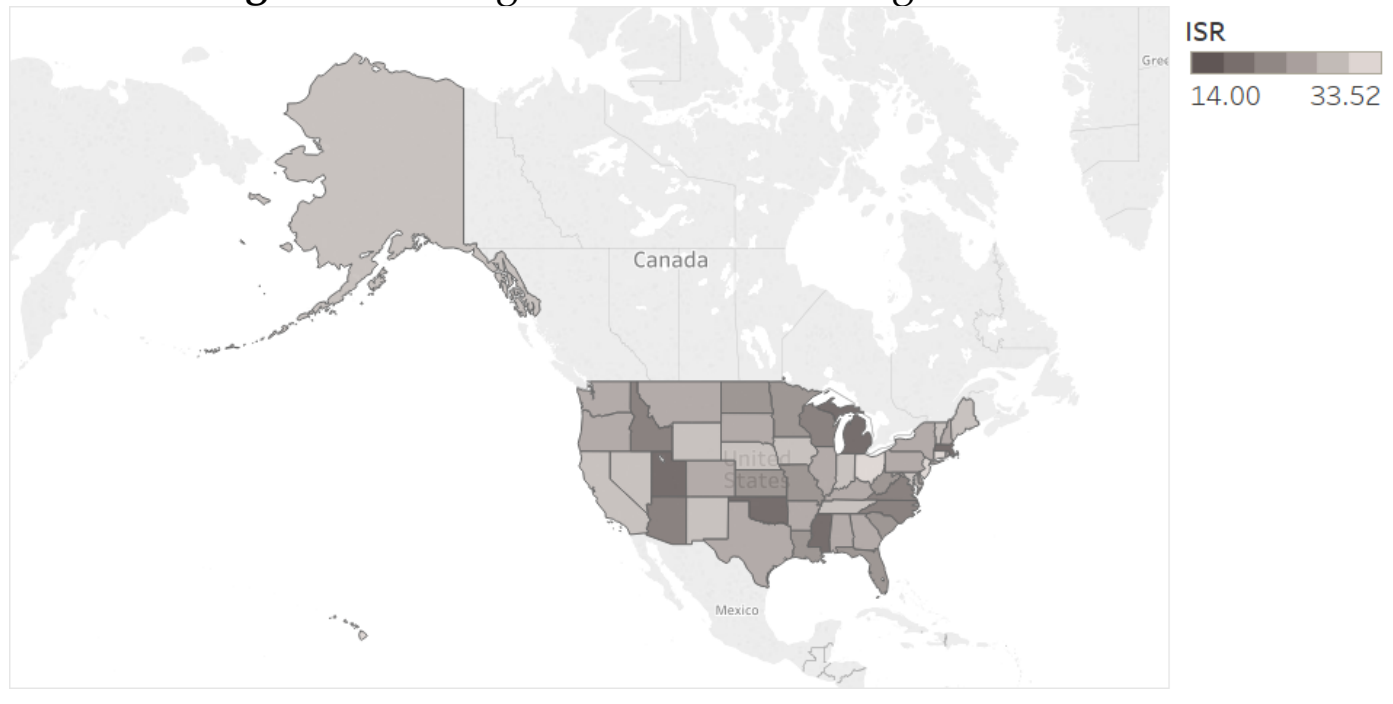

\subsection{Independent Variable}

Our first set of independent variables are the two ideology variables. For government ideology, we used the 'ADA / COPE measure of state government ideology' (Berry et al., 1998). The larger the number in both instances, the more leftist/liberal the active electorate or state government is in that state. The citizen's ideology measure come from Richard Fording's website ${ }^{6}$. The citizen ideology is the 'revised 1960-2010 citizen ideology series' (Berry et al. 1998).

Other state level variables include income, education, median age of population and population density. For income we use median household income from the U.S. Census Bureau (2011 CPI-U-RS adjusted dollars). Education data is the percent with Bachelor's degree over age 25 from the Census Bureau. Other two variables, the median age of the population in the state and population density are from the Census and stateminder website'.

Regarding the two fractionalization variables, the religious fractionalization variable is based on religion variables and includes \% Catholic, \% Evangelical, \% Protestant (mainline), \% Jews and \% other. This data comes from the Association of Religion Data Archives. $\quad$ The religion variables come out for every decade and interpolation is used for the in between years. We also construct an index of fractionalization of race variables using variables which includes \% White non-Hispanic, \% Black, and \% Hispanic. This data comes from U.S. Census Bureau (population division). Table 3 and 4 show the summary statistics and the correlation coefficients respectively.

${ }^{6} \mathrm{http}: / /$ rcfording.wordpress.com/state-ideology-data/ (accessed June 1, 2013).

$7 \mathrm{http://stateminder.org/variables/} \mathrm{(accessed} \mathrm{June} \mathrm{15,} \mathrm{2013).}$

8 Thearda.com (accessed October 1, 2013). 
Table 4: Summary Statistics

\begin{tabular}{lccc}
\hline & Observations & Mean & Std. Deviation \\
\hline Index of Marriage Practice Regulation (IMPR) & 1,050 & 12.404 & 2.46 \\
Index of Sex Crime Regulation (IMPR) & 1,050 & 12.026 & 3.26 \\
Index of Sexual Regulation (ISR) & 1,050 & 24.430 & 4.83 \\
Citizen Ideology & 1,050 & 50.339 & 15.12 \\
Government Ideology & 1,050 & 50.261 & 26.64 \\
Ln Pop Density & 1,050 & 152.117 & 192.53 \\
Ln Median HH Income & 1,050 & 10.842 & 0.16 \\
Ln \% Bachelor degree & 1,050 & 24.417 & 5.10 \\
Median Age & 1,050 & 35.441 & 2.33 \\
\% Catholic & 1,050 & 0.187 & 0.12 \\
\% Evangelical & 1,050 & 0.158 & 0.12 \\
\% Protestant & 1,050 & 0.107 & 0.07 \\
\% Jews & 1,050 & 0.011 & 0.02 \\
Racial Fractionalization Index & 1,050 & 0.339 & 0.16 \\
Religion Fractionalization Index & 1,050 & 0.590 & 0.10 \\
\hline
\end{tabular}

Table 5: Correlation Coefficients

\begin{tabular}{|c|c|c|c|c|c|c|c|c|c|c|c|}
\hline & ISR & IMPR & ISCR & $\begin{array}{l}\text { Citizen } \\
\text { ideology }\end{array}$ & $\begin{array}{l}\text { Govern } \\
\text { ment } \\
\text { Ideolo- } \\
\text { gy }\end{array}$ & $\begin{array}{l}\text { Ln } \\
\text { Pop } \\
\text { Den- } \\
\text { sity }\end{array}$ & $\begin{array}{c}\text { Ln } \\
\text { Median } \\
\text { HH } \\
\text { Income }\end{array}$ & $\begin{array}{c}\text { Ln \% } \\
\text { Bache- } \\
\text { lor } \\
\text { degree }\end{array}$ & $\begin{array}{l}\text { Median } \\
\text { Age }\end{array}$ & $\begin{array}{c}\text { Racial } \\
\text { Fracti-on } \\
\text { alism }\end{array}$ & $\begin{array}{c}\text { Religious } \\
\text { Fractiona- } \\
\text { lisation }\end{array}$ \\
\hline ISR & 1.00 & & & & & & & & & & \\
\hline IMPR & 0.79 & 1.00 & & & & & & & & & \\
\hline ISCR & 0.89 & 0.42 & 1.00 & & & & & & & & \\
\hline Citizen Ideology & 0.27 & 0.23 & 0.23 & 1.00 & & & & & & & \\
\hline Government Ideology & 0.19 & 0.24 & 0.10 & 0.60 & 1.00 & & & & & & \\
\hline Ln Pop Density & 0.20 & 0.22 & 0.12 & 0.48 & 0.28 & 1.00 & & & & & \\
\hline Ln Median HH Income & 0.27 & 0.26 & 0.21 & 0.35 & 0.14 & 0.42 & 1.00 & & & & \\
\hline Ln \% Bachelor degre & 0.16 & 0.24 & 0.06 & 0.43 & 0.18 & 0.43 & 0.75 & 1.00 & & & \\
\hline Median Age & 0.21 & 0.05 & 0.27 & 0.46 & 0.30 & 0.26 & 0.06 & 0.28 & 1.00 & & \\
\hline Racial Fractionalization & 0.11 & 0.28 & -0.04 & 0.05 & 0.10 & 0.23 & 0.22 & 0.26 & -0.09 & 1.00 & \\
\hline Religious Fractionalization & 0.02 & -0.05 & 0.07 & 0.03 & 0.01 & 0.15 & -0.25 & -0.13 & 0.24 & -0.06 & 1.00 \\
\hline
\end{tabular}




\section{Results}

We investigate the determinants of sexual practices regulation (ISR) and its sub-components, index of marriage practice regulation (IMPR) and index of sex-crime regulation (ISCR) using spatial lag fixed effects estimators. For each of the three dependent variables, we estimate three alternative specifications. First, we start with including two ideology variables. We then introduce state median household income, median age, education and population density. We then add two fractionalization variables- namely religions and racial fractionalization.

Table 6: Determinants of sexual practices' regulation (ISR)- Spatial Panel Data Estimation

\begin{tabular}{lcccc}
\hline & $(1)$ & $(2)$ & $(3)$ & $(4)$ \\
\hline & $\begin{array}{c}\text { Main } \\
\text { regression }\end{array}$ & $\begin{array}{c}\text { Direct } \\
\text { effect }\end{array}$ & $\begin{array}{c}\text { Indirect } \\
\text { effect }\end{array}$ & $\begin{array}{c}\text { Total } \\
\text { effect }\end{array}$ \\
\hline Citizen Ideology & $\begin{array}{c}0.030^{* * *} \\
(0.006)\end{array}$ & $\begin{array}{c}0.031^{* * *} \\
(0.006)\end{array}$ & $\begin{array}{c}0.007^{* * *} \\
(0.002)\end{array}$ & $\begin{array}{c}0.038^{* * *} \\
(0.008)\end{array}$ \\
Government Ideology & $-0.007^{* * *}$ & $-0.007^{* * *}$ & $-0.002^{* * *}$ & $-0.009^{* * *}$ \\
& $(0.002)$ & $(0.002)$ & $(0.001)$ & $(0.003)$ \\
Lambda & $0.233^{* * *}$ & & & \\
& $(0.051)$ & & & \\
Observations & & & & \\
Number of states & 1,050 & 1,050 & 1,050 & 1,050 \\
\hline
\end{tabular}

Notes: Estimation done using spatial lag fixed effects panel data estimation. Coefficients reported are the sum of direct and indirect effects from contiguous states. Lambda is the coefficient estimate of the spatially lagged dependent variable. Standard errors obtained using delta method. ${ }^{* * *} \mathrm{p}<0.01,{ }^{* *} \mathrm{p}<0.05,{ }^{*} \mathrm{p}<0.1$

We begin by examining various factors affecting the ISR in Table 6 . Column 1 presents the estimate of equation 1. While government ideology has slight negative impact on ISR, citizen ideology has a positive and statistically significant impact. We cannot however ascertain the magnitude of these coefficients from column 1 . The estimate of the coefficient on the spatially lagged dependent variable is positive and statistically significant. This implies that there is interdependence between a state and its neighbors in the strictness of ISR. The indirect effect captures the impact that covariate has on the conditional mean of the dependent variable in other states, while the direct impact captures the average effect within a state (LeSage and Pace, 2009).

In column 2, we provide the direct impact of a state's own characteristics on its ISR while column 3 reports the indirect or spillover effects. Both citizen and government ideologies have statistically significant average direct and indirect 
effects but the direct effect is roughly three times larger than indirect effects. Since a higher ISR denotes less regulation of sexual practices, our results indicate that a more liberal citizen ideology is associated with a lower regulation of sexual practices. Interestingly, liberal government ideology is associated with a more regulated sexual practice index, though the magnitude is very small.

Table 7: Determinants of Sexual Practices' Regulation (ISR) - Spatial Panel Data Estimation

\begin{tabular}{lcc}
\hline & $(1)$ & $(2)$ \\
\hline Citizen Ideology & & $0.019^{* * *}$ \\
& $(0.007)$ & $(0.007)$ \\
Government Ideology & $-0.006^{* *}$ & $-0.005^{* *}$ \\
& $(0.002)$ & $(0.002)$ \\
Ln Pop Density & $1.421^{* *}$ & $1.901^{* * *}$ \\
& $(0.607)$ & $(0.737)$ \\
Ln Median HH Income & $1.404^{* *}$ & $1.395^{*}$ \\
Ln \% Bachelor degree & $(0.702)$ & $(0.760)$ \\
& -0.013 & -0.003 \\
Median Age & $(0.026)$ & $(0.028)$ \\
Religious Fractionalization Index & $0.120^{* *}$ & $0.196^{* * *}$ \\
\hline Racial Fractionalization Index & $(0.049)$ & $(0.058)$ \\
& & -0.543 \\
& & $(0.970)$ \\
& & $8.584^{* *}$ \\
& & $(3.556)$ \\
\hline
\end{tabular}

Notes: Estimation done using spatial lag fixed effects panel data estimation. Coefficients reported are the sum of direct and indirect effects from contiguous states. Lambda is the coefficient estimate of the spatially lagged dependent variable. Standard errors obtained using delta method in parentheses*** $\mathrm{p}<0.01,{ }^{* *} \mathrm{p}<0.05,{ }^{*} \mathrm{p}<0.1$

We next include four socio-economic independent variables- population density, median household income, \% of population with a bachelor's degree and median age (Table 7). To save space, we report the coefficients of their total effects (sum of direct and spatial spillover). Citizen ideology continues to be associated with less regulation, along with population density, median household income and median age. The coefficient on education is not statistically significant. In column 2 we also add racial and religious 
fractionalization variables. While racial fractionalization is not statistically significant, religious fractionalization has a positive and statistically significant estimate indicating that more religious diversity is associated with a weaker index of sexual regulation. All other independent variables, except education, continue to be statistically significant with the same signs as in column 1. Also, in both model specifications, the estimate of spatially lagged dependent variable is statistically significant.

We now turn to the two sub-components of ISR. Table 8 provides results for the Index of Marriage Practice Regulation (IMPR).

Table 8: Determinants of Marriage Practice Regulation (IMPR)- Spatial Panel Data Estimation

\begin{tabular}{lccc}
\hline & $(1)$ & $(2)$ & $(3)$ \\
\hline Citizen Ideology & & & -0.002 \\
& $0.009 * *$ & -0.003 & $(0.004)$ \\
Government Ideology & $(0.003)$ & $(0.004)$ & $0.003^{* * *}$ \\
& $0.002^{*}$ & $0.003^{* * *}$ & $(0.001)$ \\
Ln Pop Density & $(0.001)$ & $(0.001)$ & 0.469 \\
& & 0.242 & $(0.365)$ \\
Ln Median HH Income & & $(0.330)$ & 0.493 \\
& & 0.462 & $(0.380)$ \\
Ln \% Bachelor degree & & $(0.380)$ & $0.035^{* *}$ \\
& & $0.031^{* *}$ & $(0.014)$ \\
Median Age & & $(0.014)$ & $0.066 * *$ \\
Religious Fractionalization Index & & $0.075 * * *$ & $(0.029)$ \\
& & $(0.027)$ & $-0.880^{*}$ \\
\hline Observations & & & $(0.482)$ \\
& & & -1.620 \\
& & & $(1.777)$ \\
\hline
\end{tabular}

Notes: Estimation done using spatial lag fixed effects panel data estimation. Coefficients reported are the sum of direct and indirect effects from contiguous states. Lambda is the coefficient estimate of the spatially lagged dependent variable. Standard errors obtained using delta method in parentheses ${ }^{* * *} \mathrm{p}<0.01,{ }^{* *} \mathrm{p}<0.05,{ }^{*} \mathrm{p}<0.1$

Unlike in the case of ISR, both the ideology variables in column 1 are positive and statistically significant. Thus, a more liberal citizen and government ideology is associated with less regulation on marriage practice. When we include the four 
socio-economic variables in column 2, citizen's ideology is no longer statistically significant but government ideology continues to be positive and statistically significant, along with the education and age variables. In column 3, we also include racial and religious fractionalization variables. The results are very similar to column 2. In addition, a greater degree of racial fractionalization is associated with a more regulated or less liberal marriage practice index.

Table 9: Determinants of Sex Crime Regulation (ISCR) - Spatial Panel Data Estimation

\begin{tabular}{lccc}
\hline & $(1)$ & $(2)$ & $(3)$ \\
\hline Citizen Ideology & & & \\
& $0.009^{* *}$ & -0.003 & -0.002 \\
Government Ideology & $(0.003)$ & $(0.004)$ & $(0.004)$ \\
& $0.002^{*}$ & $0.003^{* * *}$ & $0.003^{* * *}$ \\
Ln Pop Density & $(0.001)$ & $(0.001)$ & $(0.001)$ \\
& & 0.242 & 0.469 \\
Ln Median HH Income & & $(0.330)$ & $(0.365)$ \\
& & 0.462 & 0.493 \\
Ln \% Bachelor degree & & $(0.380)$ & $(0.380)$ \\
& & $0.031^{* *}$ & $0.035^{* *}$ \\
Median Age & & $(0.014)$ & $(0.014)$ \\
Religious Fractionalization Index & & $0.075^{* * *}$ & $0.066^{* *}$ \\
Rumber of states & & $(0.027)$ & $(0.029)$ \\
& & & $-0.880^{*}$ \\
& & & $(0.482)$ \\
& & & -1.620 \\
& & & $(1.777)$ \\
\hline
\end{tabular}

Notes: Estimation done using spatial lag fixed effects panel data estimation. Coefficients reported are the sum of direct and indirect effects from contiguous states. Lambda is the coefficient estimate of the spatially lagged dependent variable. Standard errors obtained using the delta method in parentheses. ${ }^{* *} \mathrm{p}<0.01,{ }^{* *} \mathrm{p}<0.05,{ }^{*} \mathrm{p}<0.1$

Finally, Table 9 reports factors affecting the Index of Sex Crime Regulation (ISCR). In the case of ISCR, the coefficient estimate of the spatially lagged dependent variable was not statistically significant, indicating the absence of across-state spillover effects. Hence, we only report the direct effects of the covariates on ISCR. Column 1 indicates that a more leftist citizen's ideology is associated with a less regulation of sex crimes while government ideology has a 
negative association indicating a more leftist ideology sees more regulation of sex crimes. Including other state-level covariates does not affect the magnitude or statistical significance of these variables. In addition, population density and median income are associated with a freer ISCR while education is associated with more regulation (column 2). In column 3, we also include the race and religion fractionalization variables. Citizen ideology and government ideology continue to have the same signs and statistical significance. Education continues to be associated with more regulation while population density, median age and religious fractionalization are associated with a less regulation of sex crimes.

\section{Conclusions}

Using a novel dataset, this paper investigates various factors affecting regulations of sexual practices in the United States, as well as two underlying dimensions, marriage practice regulations and sex-crime regulations. We account for the cross-state spillovers in the dependent variables as well as unobserved state-specific heterogeneity using a spatial lag fixed effects estimator. We find that median household income has a positive impact on ISR, supporting the hypothesis that reducing sexual regulations is a normal good. A key result is that more liberal citizen ideology has a positive impact on ISR while government ideology has a negative, albeit relatively smaller, impact on ISR. This result is robust to inclusion of various demographic controls. Another finding of this paper is that percentage of population with a bachelor's degree or above has the effect of weakening marriage practice regulations but has the opposite effect on sex-crime regulations. Based on our findings, we conclude that marriage practice regulations are positively impacted by a more leftist government ideology, higher median age and education. Finally, citizen ideology, median age and population density positively impact sex crime regulations whereas government ideology, percentage of population with Bachelor's degree and religious fractionalization as associated with a lower index of sex crime regulations.

Some improvements can be made in a future work. Regulation around sexual practices evolves incrementally. Our sample covers the past twenty-one years but the index has been relatively stable within each state. It would be of interest to see how these indices have evolved over the longer period of time. 


\section{References}

Allen, D. W., Pendakur, K., Suen, W., 2006. No-Fault Divorce and the Compression of Marriage Ages. Economic Inquiry 44, 547-558.

Andersen, R., Fetner, T. 2008. Economic Inequality and Intolerance: Attitudes toward Homosexuality in 35 Democracies. American Journal of Political Science 52, 942-958.

Becker, G.S., 1981. A Treatise on the Family. Cambridge, MA, Harvard University Press.

Berggren, N., Nilsson, T., 2013. Does Economic Freedom Foster Tolerance? Kyklos 66, 177-207.

Berry, W.D., Ringquist, E.J., Fording, R.C., Hanson, R.L., 1998. Measuring Citizen and Government Ideology in the American States, 1960-93. American Journal of Political Science 42, 327-348.

Bose, F., 2015. The Determinants of Sexual Freedom from 1990 to 2010. Applied Economics Letters 22, 1224-1229.

Botti, F., D'ippoliti, C. 2014. Don't Ask Don't tell (That you're poor). Sexual Orientation and Social Exclusion in Italy. Journal of Behavioral and Experimental Economics 49, 8-25.

Cameron, S., 2002. The Economics of Sin: Rational Choice or No Choice At All?, Cheltenham, UK, Edward Elgar.

Coleman, P., 1991. Who's Been Sleeping in My Bed? You and Me, and the State Makes Three. Indiana Law Review 24, 399-416.

Cooter, R.D., 1997. The Rule of State Law and the Rule-of-Law State: Economic Analysis of the Legal Foundations of Development. The International Bank for Reconstruction and Development/The World Bank, 191-217.

Fagan, P.F., Churchill, A. 2012. The Effects of Divorce on Children. Marriage ad Religion Research Institute (Marri) Research Papers

http://marri.us/wp-content/uploads/The-Effects-of-Divorce-on-Children.pdf

Frank, D.J., Camp, B.J., Boutcher, S.A. 2010. Worldwide Trends in the Criminal Regulation of Sex, 1945 to 2005 . American Sociological Review 75, 867-893.

Freud, S. 1908. 'Civilized' Sexual Morality and Modern Nervousness.

Friedberg, L., 1998. Did Unilateral Divorce Raise Divorce Rates? Evidence from Panel Data. American Economic Review 88, 608-627.

Huxley, A. 1932. Brave New World.

Lee, L.-F., Yu, J. 2010. Estimation of Spatial Autoregressive Panel Data Models with Fixed Effects. Journal of Econometrics 154, 165-185.

LeSage, J., Pace, R.K., 2009. Introduction to Spatial Econometrics. Bpca Raton, Chapman and Hall/CRC. 
Mallory, C., Sears, B., Brown, T.N.T., Toomey, R., 2018. The Impact of Stigma and Discrimination against LGBT People in Arizona. The Williams Institute: UCLA School of Law.

Matouschek, N., Rasul, I., 2008. The Economics of the Marriage Contract: Theories and Evidence. Journal of Law and Economics, 51, 59-110.

Murray, M., 2009. Strange Bedfellows: Criminal Law, Family Law and the Legal Construction of Intimate Life. Iowa Law Review 94, 1253-1313.

Olasky, M., 1995. Abortion Rites: A Social History of Abortion in America, Washington D.C., Regnery Publishing, Inc.

Peters, H.E., 1986. Marriage and Divorce: Informational Constraints and Private Contracting. American Economic Review 76, 437-454.

Posner, R.A., 1997. Social Norms and the Law: An Economic Approach. American Economic Review: Papers and Proceedings 87, 365-369.

Posner, R.A., 2007. Economic Analysis of Law, New York, Wolters Kluwer Law \& Business.

Rasul, I., 2006. Marriage Markets and Divorce Laws. The Journal of Law, Economics, \& Organization 22, 30-69.

Ruger, W.P., Sorens, J., 2016. Freedom in the 50 States: An Index of Personal and Economic Freedom, 4th edition. Cato Institute, Washington.

Smock, E., 2004. What if Roe Fell? The State-by-State Consequences of Overturning Roe v. Wade. New York: Center for Reproductive Rights.

Sorokin, P.A., 1956. American Sex Revolution, Boston, Porter Sargent.

Torcia, C.E., 1993. Wharton's Criminal Law 15th edition, New York, Clark Boardman Callaghan.

Unwin, J.D., 1934. Sex and Culture, London, Oxford University Press.

Unwin, J.D., 1935. Sexual Regulations and Cultural Behaviour, London, Oxford University Press.

Unwin, J.D., 1940. HOPOUSIA or The Sexual and Economic Foundations of a New Society, New York, Oskar Piest.

Wolfers, J., 2006. Did Unilateral Divorce Laws Raise Divorce Rates? A

Reconciliation and New Results. American Economic Review 96, 1802-1820. 